\title{
TUMOR NECROSIS FACTOR-ALPHA LEVEL IN SERA OF SOUTH INDIAN PATIENTS WITH RHEUMATOID ARTHRITIS: CORRELATION WITH ANTICYCLIC CITRULLINATED PEPTIDE ANTIBODY LEVEL
}

\author{
NATESAN MANIKANDAN, NARASINGAM ARUNAGIRINATHAN*, PRIYA K, NALLUSAMY VIJAYKANTH, \\ MARIMUTHU RAGAVAN RAMESHKUMAR, SETHURAMALINGAM BALAKRISHNAN
}

Department of Microbiology \& Biotechnology, Presidency College, Chennai - 600 005, Tamil Nadu, India. Email: n_arunagiri@yahoo.co.in

Received: 23 July 2016, Revised and Accepted: 04 October 2016

\section{ABSTRACT}

Objective: The present study was aimed to find out the anticyclic citrullinated peptide (CCP) antibody level and expression level Th2 cytokine-like tumor necrosis factor-alpha (TNF- $\alpha$ ) in patients with rheumatoid arthritis (RA) from South India.

Methods: The patients attending the Arthritis and Rheumatism Care Centre, Vadapalani, Chennai and healthy individuals from the Presidency College, Chennai, were enrolled for this study. The study group included 74 patients with RA and 50 healthy individuals without history of RA. 3-5 ml of blood samples was aseptically collected using Vacutainer, and the separated serum samples were transported to the Department of Microbiology, Presidency College, Chennai, Tamil Nadu, in cold chain. Anti-CCP antibodies were detected by enzyme-linked immunosorbent assay (ELISA). Serum concentrations of TNF- $\alpha$ were studied in patients with RA and in healthy controls, using an ELISA method.

Results: The results of anti-CCP enzyme immunoassay revealed that out of 74 patients, all were anti-CCP positive, which included 65 females and 9 males. Higher levels of anti-CCP (456 IU/ml) were present in the age group between 41 and 50 followed by 21-30 years age group which shows $335.28 \mathrm{IU} / \mathrm{ml}$ of anti-CCP antibody level. The level of serum TNF- $\alpha$ was measured in the range of $4.6-1082.84 \mathrm{pg} / \mathrm{ml}$ for RA patients and $6.630-459.74 \mathrm{pg} / \mathrm{ml}$ for the healthy control group.

Conclusion: TNF- $\alpha$ levels were significantly increased in RA patients compared to healthy individuals. A negative correlation was found between antiCCP antibody and TNF- $\alpha$ level in RA patients.

Keywords: Rheumatoid arthritis, Tumor necrosis factor-alpha, Enzyme-linked immunosorbent assay, Anticyclic citrullinated peptide antibodies.

(C) 2017 The Authors. Published by Innovare Academic Sciences Pvt Ltd. This is an open access article under the CC BY license (http://creativecommons. org/licenses/by/4. 0/) DOI: http://dx.doi.org/10.22159/ajpcr.2017.v10i1.14274

\section{INTRODUCTION}

Rheumatoid arthritis (RA) is a systemic autoimmune disease that affects several organs, and it is also associated with the destruction of joint connective tissues and bones. The joints become swollen, painful, and stiff on aggravation, which ultimately is liable to cause immobility and physical deformity. The most common chronic arthritis in rheumatology is RA. The disease is characterized by chronic inflammation starting in joint synovial membranes and spreading to cartilage and bone gradually leading to the destruction of these joints. RA is found 3-4 times more frequently in women than men [1] The prevalence of RA is $1 \%$ in the world population. The majority of the prevalence studies carried out in Northern European, and North American countries estimate a prevalence of $0.5-1.1 \%$, whereas the annual incidence varies between 20 and 50 cases per 100,000 inhabitants [2]. Anticitrullinated peptide/protein antibodies (ACPA) appear early in the rheumatic disease process and remain throughout the course of RA [3]. Cyclic citrullinated peptide (CCP) is the most widely used antigen to detect ACPA [4]. The ACPAs bind to the citrulline epitope of the CCPs. Citrullination is a process causing modifications of positively charged arginine to neutrally charged citrulline at certain positions of autologous proteins/peptides. The change is catalyzed by the enzyme peptidylarginine deiminases (PADI), which requires $\mathrm{Ca}^{2+}$ ions for its activation. During inflammation and apoptosis cell death, cell membranes become porous and penetrable to a number of small molecules. $\mathrm{Ca}^{2+}$ ions move inside the cell increasing the intracellular concentration of $\mathrm{Ca}^{2+}$ ions a 100-1000 fold. This activates PADI resulting in citrullination of different proteins in the inflamed joints.

\section{L-Arginine(R) \\ PADI \\ $\mathrm{Ca}^{2+}$ \\ L-Citrulline}

Cytokines play a critical role in the pathogenesis of RA [5]. Development of sensitive immunoassays for cytokines has made it possible to show increased levels of some cytokines in the blood of patients with RA [6] Tumor necrosis factor-alpha (TNF- $\alpha$ ) is a proinflammatory cytokine involved in the pathogenesis of RA, and antagonism of TNF may reduce the activity of the disease [7]. Treatment with a chimeric mAb to TNF- $\alpha$ has been shown to suppress inflammation [8] and improve patient well-being in RA, but the mechanisms of action of such treatment have not been fully explored $[9,10]$. The present study aims to find out the anti-CCP antibody level and expression level of Th2 cytokine-like TNF- $\alpha$ in patients with RA from South India.

\section{METHODS}

\section{Study population}

Patients details such as age, sex, history of RA, and autoimmune markers were recorded in the prescribed pro forma formatted for this study. The patients attending the Arthritis and Rheumatism Care Centre, Vadapalani, Chennai and healthy individuals from the Presidency College, Chennai, were enrolled for this study. The study group included 74 patients with RA and 50 healthy individuals without history of RA. This study was approved by the Ethical Committee (No: 15102013) of Madras Medical College and Hospital, Chennai, Tamil Nadu, and an informed written consent was obtained from each participant. 
Collection, transport, and storage of clinical specimens

For laboratory diagnosis of RA, 3-5 ml of blood samples was aseptically collected using Vacutainer (BD Bioscience), and the separated serum samples were transported to the Department of Microbiology, Presidency College, Chennai, Tamil Nadu, in cold chain. The serum samples were labeled and stored in standard screw capped leak proof vials and frozen at $-20^{\circ} \mathrm{C}$ until further processed.

\section{Anti-CCP antibody}

Anti-CCP antibodies were detected by enzyme-linked immunosorbent assay (ELISA) kit obtained from Orgentec, Germany. This assay was performed with the patient's sera according to the manufacturer's instructions. CCP is bound to microwells. Antibodies against this antigen, if present in diluted serum, bind to the respective antigen. Washing of the microwells removes unspecific serum components. Horseradish peroxidase conjugated with antibody against anti-CCP antibody immunologically detects the bound patient ACPA forming a conjugate/antibody/antigen complex. Washing of the microwells removes unbound conjugate. An enzyme substrate in the presence of bound conjugate hydrolyzes to form a blue color. The addition of an acid stops the reaction forming a yellow end product. The intensity of this yellow was measured photometrically at $450 \mathrm{~nm}$. This intensity of color was directly proportional to the concentration of anti-CCP antibodies in the original sample.

\section{TNF- $\alpha$ ELISA}

Serum concentrations of TNF- $\alpha$ were studied in patients with RA at various degrees of disease activity and in healthy controls, using an ELISA kit obtained from eBioscience, USA. The human TNF- $\alpha$ kit is a solid phase sandwich ELISA. A polyclonal antibody specific for human TNF- $\alpha$ has been coated onto the wells of the microtiter plate. Samples, including standards of known human recombinant TNF- $\alpha$ concentrations, and unknown were pipetted into these wells. During the first incubation, the human TNF- $\alpha$ antigen and a biotinylated polyclonal antibody specific for human TNF- $\alpha$ were simultaneously incubated. After washing, the enzyme (streptavidin-peroxidase) was added. After incubation and washing to remove the entire unbound enzyme, a substrate solution which is acting on the bound enzyme was added to induce a colored reaction product. The intensity of this colored product was directly proportional to the concentration of human TNF- $\alpha$ present in the samples.

\section{Statistical analysis}

Data are presented as means \pm standard deviation. Statistical Package for the Social Sciences package 20 for Windows was used. Differences in mean levels between the groups were determined by Chi-square test. A $p \leq 0.05$ was considered statistically significant. Furthermore, correlation study was performed between the TNF- $\alpha$ and anti-CCP antibody level in RA patients.

\section{RESULTS}

\section{Age-wise distribution of RA patients}

Table 1 shows the demographic characteristics of RA patients. Age group analysis of RA patients revealed the maximum number of positive cases among the age group 41-50 (31\%), followed by 31-40 (30\%) and 21-30 (19\%) years age groups. The number of RA cases has been drastically declined after 51-60 years (14\%), and the minimum positivity was present in $71-80$ years $(1.35 \%)$ (Table 2 ).

\section{Gender-wise distribution of RA patients}

In the gender-wise distribution of RA, there was a preponderance of females 65 (87.83\%) when compared with males 9 (12.16\%).

\section{Anti-CCP antibody levels}

Samples from 74 patients with symptoms more likely for RA were collected. Out of the 74 samples, $65(88 \%)$ were of females and $9(12 \%)$ of males. The results of anti-CCP enzyme immunoassay revealed that out of 74 patients, all were anti-CCP positive, which included 65 females and 9 males. Higher levels of anti-CCP $(456 \mathrm{IU} / \mathrm{ml})$ were present in the age group between 41 and 50 followed by 21-30 years age group which shows $335.28 \mathrm{IU} / \mathrm{ml}$ of anti-CCP antibody level (Table 3).

\section{TNF- $\alpha$ levels}

The levels of TNF- $\alpha$ in serum were estimated in 74 RA patients and 50 healthy volunteers. The level of serum TNF- $\alpha$ was measured in the range of $4.6-1082.84 \mathrm{pg} / \mathrm{ml}$ for RA patients and $6.630-459.74 \mathrm{pg} / \mathrm{ml}$ for healthy control group. TNF- $\alpha$ level was highest in patients with RA when compared to normal individuals. The mean level of TNF- $\alpha$ in RA patients and healthy individuals were $358 \pm 156$ and $85 \pm 95 \mathrm{pg} / \mathrm{ml}$, respectively. A negative correlation was noted between anti-CCP antibody and TNF- $\alpha$ levels in RA patients $(r=-0.008)(p=0.947)$ (Table 4). TNF- $\alpha$ levels were significantly increased in SLE patients compared with healthy individuals $(\mathrm{p}=0.0001)$ (Table 5). A significant inverse correlation was obtained between erythrocyte sedimentation rate and TNF- $\alpha$ levels ( $r=-0.2 ; p=0.03$ ) (Table 6 and Fig. 1).

\section{DISCUSSION}

In the present study, 74 patients were positive for anti-CCP antibodies ranged from 21.1 to $804.7 \mathrm{IU} / \mathrm{ml}$. Higher mean values of anti-CCP

Table 1: Demographic characteristics of RA patients

\begin{tabular}{ll}
\hline Findings & Mean \pm SD values \\
\hline Age & $40 \pm 9$ years \\
Gender (female/male) & $65 / 9$ \\
ESR level & $60 \pm 20 \mathrm{~mm} / \mathrm{h}$ \\
CRP level & $15 \pm 8 \mathrm{mg} / \mathrm{dl}$ \\
Anti-CCP antibody level & $245 \pm 205 \mathrm{IU} / \mathrm{ml}$ \\
TNF- $\alpha$ level & $358 \pm 156 \mathrm{pg} / \mathrm{ml}$ \\
\hline
\end{tabular}

TNF- $\alpha$ : Tumor necrosis factor-alpha, CCP: Cyclic citrullinated peptide,

ESR: Erythrocyte sedimentation rate, CRP: C-reactive protein, RA: Rheumatoid arthritis, SD: Standard deviation

Table 2: Age-wise distribution of RA cases

\begin{tabular}{llll}
\hline S.No. & Age group in years & RA cases & Percentage \\
\hline 1 & $1-10$ & - & - \\
2 & $11-20$ & 3 & 4.05 \\
3 & $21-30$ & 14 & 18.9 \\
4 & $31-40$ & 22 & 29.7 \\
5 & $41-50$ & 23 & 31.0 \\
6 & $51-60$ & 11 & 14.8 \\
7 & $61-70$ & - & - \\
8 & $71-80$ & 1 & 1.3 \\
Total & & 74 & 100 \\
\hline
\end{tabular}

RA: Rheumatoid arthritis

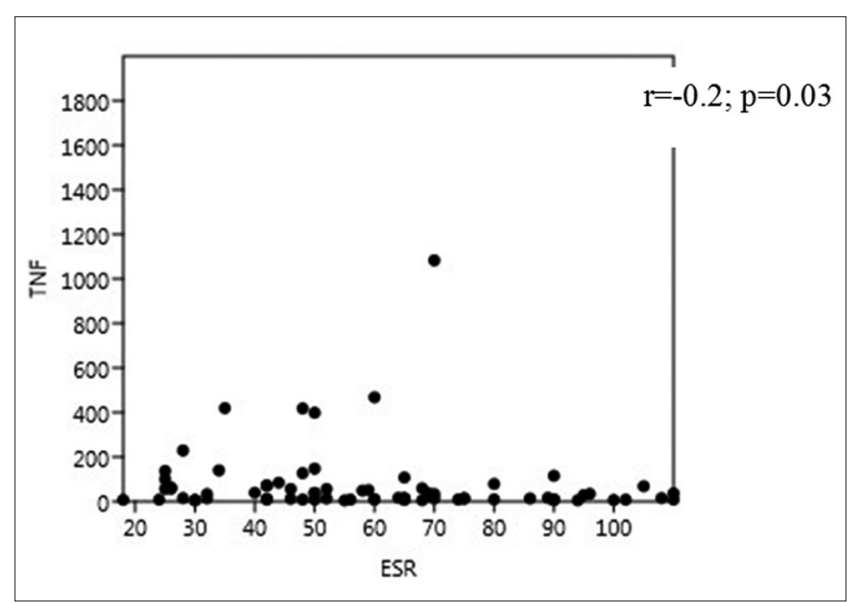

Fig. 1: Correlation between erythrocyte sedimentation rate and tumor necrosis factor-alpha levels in rheumatoid arthritis patients 
Table 3: Mean values of anti-CCP antibodies in RA patients

\begin{tabular}{|c|c|c|c|c|c|}
\hline \multirow[t]{2}{*}{ Age group in years } & \multirow[t]{2}{*}{ Total number of subjects } & \multicolumn{2}{|c|}{ Mean $\pm S D$ of anti-CCP } & \multicolumn{2}{|c|}{ Mean \pm SD of TNF- $\alpha$} \\
\hline & & Female & Male & Female & Male \\
\hline $11-20$ & 3 & $95.3 \pm 94.35$ & 0 & $81 \pm 98$ & 0 \\
\hline $21-30$ & 14 & $292.78 \pm 256.88$ & $42.5 \pm 0$ & $63 \pm 67$ & $14 \pm 25$ \\
\hline $31-40$ & 22 & $291.68 \pm 213.58$ & $30.5 \pm 0$ & $44 \pm 26$ & $393 \pm 460$ \\
\hline $41-50$ & 23 & $231.22 \pm 246.78$ & $225.5 \pm 0$ & $22 \pm 20$ & $33 \pm 23$ \\
\hline$>50$ & 12 & $198.12 \pm 251.76$ & $274.9 \pm 259.32$ & $44 \pm 43$ & $140 \pm 172$ \\
\hline
\end{tabular}

RA: Rheumatoid arthritis, CCP: Cyclic citrullinated peptide, TNF- $\alpha$ : Tumor necrosis factor-alpha, SD: Standard deviation

Table 4: Correlation of anti-CCP antibodies and TNF- $\alpha$ in RA patients

\begin{tabular}{lllll}
\hline Age group in years & Total number of patients & Mean \pm SD of anti-CCP & Mean \pm SD of TNF- $\boldsymbol{\alpha}$ & p values \\
\hline $11-20$ & 3 & $95.3 \pm 94.35$ & $81 \pm 98$ & $0.3(\mathrm{NS})$ \\
$21-30$ & 14 & $197 \pm 103$ & $60 \pm 63$ & $0.0006(\mathrm{~S})$ \\
$31-40$ & 22 & $178 \pm 99$ & $91 \pm 97$ & $0.2(\mathrm{NS})$ \\
$41-50$ & 23 & $235 \pm 8$ & $67 \pm 68$ & $0.0001(\mathrm{~S})$ \\
$>50$ & 12 & $242 \pm 29$ & $70 \pm 81$ & $0.0004(\mathrm{~S})$ \\
\hline
\end{tabular}

S: Significant, NS: Nonsignificant, RA: Rheumatoid arthritis, CCP: Cyclic citrullinated peptide, TNF- $\alpha$ : Tumor necrosis factor-alpha, SD: Standard deviation

Table 5: TNF- $\alpha$ levels in RA patients and healthy individuals

\begin{tabular}{llll}
\hline Variable & RA patients & Healthy individuals & t value \\
\hline $\begin{array}{l}\text { TNF- } \boldsymbol{\alpha} \text { levels } \\
\text { (mean } \pm \text { SD) }\end{array}$ & $358 \pm 156 \mathrm{pg} / \mathrm{ml}$ & $85 \pm 95 \mathrm{pg} / \mathrm{ml}$ & $0.0001(\mathrm{~S})$ \\
\hline
\end{tabular}

S: Significant, SD: Standard deviation, TNF- $\alpha$ : Tumor necrosis factor-alpha, RA: Rheumatoid arthritis

Table 6: Correlation between anti-CCP antibody and TNF- $\alpha$ levels in RA patients

\begin{tabular}{|c|c|c|c|c|}
\hline \multirow{2}{*}{$\begin{array}{l}\text { Number } \\
\text { of RA } \\
\text { patients }\end{array}$} & \multicolumn{2}{|l|}{ Mean \pm SD } & \multirow[t]{2}{*}{$r$ value } & \multirow[t]{2}{*}{$p$ value } \\
\hline & $\begin{array}{l}\text { Anti-CCP } \\
\text { antibody }\end{array}$ & TNF- $\alpha$ levels & & \\
\hline 74 & $245 \pm 205 \mathrm{IU} / \mathrm{ml}$ & $358 \pm 156 \mathrm{pg} / \mathrm{ml}$ & -0.008 & 0.947 (NS) \\
\hline
\end{tabular}

NS: Nonsignificant, RA: Rheumatoid arthritis, CCP: Cyclic citrullinated peptide, TNF- $\alpha$ : Tumor necrosis factor-alpha, SD: Standard deviation

(mean $456 \mathrm{IU} / \mathrm{ml}$ ) were present in the age group between 41 and 50 followed by 21-30 years age group which shows mean values $335.28 \mathrm{IU} / \mathrm{ml}$ for anti-CCP antibody level. In another study in Japan, Inui et al. (2008) reported anti-CCP antibodies were positive in 48 (56\%) patients with RA [11]. The levels of anti-CCP antibodies were $35.6 \pm 35.2 \mathrm{IU} / \mathrm{ml}$. In China, Liao et al. reported anti-CCP antibodies in $31.91 \% 75$ patients with RA [12]. In their study, anti-CCP antibodies were ranged from 27 to $32,940 \mathrm{IU} / \mathrm{ml}$. Results of our study differ with their results.

In the present study, the level of serum TNF- $\alpha$ was measured in the range of $8.6-1082.84 \mathrm{pg} / \mathrm{ml}$ for RA patients and $6.630-459.74 \mathrm{pg} / \mathrm{ml}$ for the healthy control group. TNF- $\alpha$ level was highest in patients with RA when compared to normal individuals. Straub et al. from Germany reported increased serum levels of TNF- $\alpha$ level $(450 \mathrm{pg} / \mathrm{ml})$ in 22 patients with RA, whereas low level in healthy controls $(200 \mathrm{pg} / \mathrm{ml})$ [13]. In another study, Danis et al. reported TNF- $\alpha$ level in 27 patients with RA. Their results showed that the median level of TNF- $\alpha$ was $1.2 \mathrm{ng} / \mathrm{ml}$. Thus, the present study differs from earlier findings in the TNF- $\alpha$ level [6].

\section{CONCLUSION}

The result of our study suggests that TNF- $\alpha$ levels were significantly increased in RA patients compared to healthy individuals. Negative correlation was noted between anti-CCP antibody and TNF- $\alpha$ levels in RA patients.

\section{REFERENCES}

1. Ebringer A, Rashid T, Wilson C. Rheumatoid arthritis, proteus, anti-CCP antibodies and Karl Popper. Autoimmun Rev 2010;9(4):216-23.

2. Alamanos Y, Voulgari V, Drosos A. Rheumatoid arthritis in Southern Europe: Epidemiological, clinical, radiological and genetics considerations. Curr Rheumatol Rev 2005;1:33-6.

3. van Venrooij WJ, Zendman AJ, Pruijn GJ. Autoantibodies to citrullinated antigens in (early) rheumatoid arthritis. Autoimmun Rev 2006;6(1):37-41

4. Aletaha D, Neogi T, Silman AJ, Funovits J, Felson DT, Bingham CO $3^{\text {rd }}$, et al. 2010 Rheumatoid arthritis classification criteria: An American College of Rheumatology/European League Against Rheumatism collaborative initiative. Arthritis Rheum 2010;62(9):2569-81.

5. Feldmann M, Brennan FM, Maini RN. Role of cytokines in rheumatoid arthritis. Annu Rev Immunol 1996;14:397-440.

6. Danis VA, Franic GM, Rathjen DA, Laurent RM, Brooks PM. Circulating cytokine levels in patients with rheumatoid arthritis: Results of a double blind trial with sulphasalazine. Ann Rheum Dis 1992;51(8):946-50.

7. Moreland LW, Baumgartner SW, Schiff MH, Tindall EA, Fleischmann RM, Weaver AL, et al. Treatment of rheumatoid arthritis with a recombinant human tumor necrosis factor receptor (p75)- $\mathrm{Fc}$ fusion protein. N Engl J Med 1997;337(3):141-7.

8. Feldmann M, Maini RN. Discovery of TNF-alpha as a therapeutic target in rheumatoid arthritis: Preclinical and clinical studies. Joint Bone Spine 2002;69(1):12-8.

9. Charles P, Elliott MJ, Davis D, Potter A, Kalden JR, Antoni C, et al. Regulation of cytokines, cytokine inhibitors, and acute-phase proteins following anti-TNF-alpha therapy in rheumatoid arthritis. J Immunol 1999;163(3):1521-8.

10. Dayer JM. The saga of the discovery of IL-1 and TNF and their specific inhibitors in the pathogenesis and treatment of rheumatoid arthritis. Joint Bone Spine 2002;69(2):123-32.

11. Inui N, Enomoto N, Suda T, Kageyama Y, Watanabe H, Chida K. Anticyclic citrullinated peptide antibodies in lung diseases associated with rheumatoid arthritis. Clin Biochem 2008;41(13):1074-7.

12. Liao J, Ip WS, Cheung KY, Wan WM, Cautherley GW, Cai X, et al. Diagnostic utility of an anti-CCP point-of-care immunotest in Chinese patients with rheumatoid arthritis. Clin Chim Acta 2011;412(9-10):778-81.

13. Straub RH, Paimela L, Peltomaa R, Schölmerich J, Leirisalo-Repo M. Inadequately low serum levels of steroid hormones in relation to interleukin-6 and tumor necrosis factor in untreated patients with early rheumatoid arthritis and reactive arthritis. Arthritis Rheum 2002;46(3):654-62. 